\title{
PENGEMBANGAN MULTIMEDIA INTERAKTIF MATA DIKLAT MEMPERBAIKI MOTOR LISTRIK GUNA PENINGKATAN HASIL BELAJAR
}

\author{
(Development of Interactive Multimedia Course On Improving the Electric Motors For \\ Improvement of Learning Outcomes)
}

\section{Oleh: Oriza Candra*) Fivia Eliza*) Syaiful Islami*) Yosri Alisman*) \\ Email. syaiful_islami@ft.unp.ac.id}

*) Pendidikan Teknik Elektro, Fakultas Teknik, Universitas Negeri Padang

\begin{abstract}
The purpose of this article is to improve the learning outcomes of students using interactive multimedia in the eyes of training to improve electric motors in SMK 1 Tanjung Raya. This type of research is a quasi-experimental design with a pretest-posttest one group. The subjects of this study were students of class XII TITL of SMK 1 Tanjung Raya who were enrolled in the 2013/2014 school year consisting of 29 students. Data collection in this study used a test of learning outcomes (posttest) in the form of objective questions as many as 20 items. Before the test questions were used then a test was conducted to determine the validity, reliability, level of difficulty of the questions and the different power of the questions. The data obtained were analyzed using the Gain Score. The results obtained indicate that there is an increase in student learning outcomes that can be seen from the results of the pretest and posttest values, the average value of pretest before using interactive multimedia is 64.48 and the average posttest value after using interactive multimedia is 75.07. So it was concluded that the use of interactive multimedia learning media can improve student learning outcomes in the eyes of training to improve the electric motor.
\end{abstract}

Key words: interactive multimedia, improving the electric motors, learning outcome

\section{PENDAHULUAN}

Kemajuan teknologi adalah sesuatu yang tidak bisa kita hindari dalam kehidupan ini, karena kemajuan teknologi akan berjalan sesuai dengan kemajuan ilmu pengetahuan. Perkembangan teknologi memang sangat diperlukan. Setiap inovasi diciptakan untuk memberikan manfaat positif bagi kehidupan manusia. Kemajuan teknologi dapat memberikan banyak kemudahan, serta sebagai cara baru dalam melakukan aktifitas manusia. Jika dilihat pada saat sekarang ini perkembangan teknologi terutama di Indonesia semakin berkembang. Dengan adanya teknologi ini dapat memudahkan kita untuk belajar dan mendapatkan informasi yang kita butuhkan dari mana saja, kapan saja, dan dari siapa saja (Candra, Pulungan, Eliza, Elfizon, \& Syamsuarnis, 2019).

Khusus kemajuan di bidang pengetahuan dan teknologi telah membawa pengaruh besar pada bidang pendidikan. Pembaharuan di dalam bidang pendidikan membawa pengaruh sikap, perilaku nilai-nilai pada individu dan masyarakat. Untuk mencapai kemajuan dalam dunia pendidikan diperlukan strategi yang tepat dengan memperhatikan komponen-komponen yang mendukung seperti materi, media, metode, sarana dan prasarana, serta evaluasi. Seorang guru harus dapat meningkatkan suatu pembelajaran menuju tercapainya hasil belajar yang optimal. Salah satu komponen yang mendukung dalam pembelajaran adalah tentang 
pemilihan media pembelajaran yang tepat (Elfizon, Syamsuarnis, \& Candra, 2017).

Pemilihan media yang tepat dalam hal ini tidak hanya terkini dan inovatif tetapi yang terpenting adalah efektifitas media tersebut pada suatu mata pelajaran (Zaus, Wulansari, Islami, \& Pernanda, 2018). Oleh karena itu seorang guru harus menggunakan media yang tepat sehingga dapat mendukung proses pembelajaran. Pemilihan media pembelajaran yang tepat dapat membantu siswa dalam belajar yang pada gilirannya diharapkan dapat meningkatkan hasil belajar yang dicapainya. Ada beberapa alasan, mengapa media pembelajaran dapat mempertinggi proses belajar siswa. Alasan pertama dengan menggunakan media pembelajaran, pengajaran akan lebih menarik perhatian siswa sehingga dapat menumbuhkan motivasi belajar siswa. Alasan kedua dengan menggunakan media pembelajaran, bahan pengajaran akan lebih jelas maknanya sehingga dapat lebih dipahami oleh para siswa dan alasan ketiga dengan menggunakan media pembelajaran, siswa lebih banyak melakukan kegiatan belajar, sebab siswa tidak hanya mendengarkan uraian guru, tetapi juga aktivitas lain seperti mengamati, melakukan, mendemonstrasikan dan lain-lain.

Perkembangan teknologi informasi yang semakin pesat, salah satunya dipengaruhi oleh perkembangan komputer yang semakin pesat pula. Sehingga dapat dikatakan, dalam perkembangannya kedua teknologi ini saling berkaitan erat dan akan senantiasa berjalan beriringan. Salah satu aplikasi dari kedua teknologi ini yang sekarang sedang dikembangkan dalam dunia pendidikan adalah pembuatan media pembelajaran. Media pembelajaran merupakan seperangkat alat bantu atau pelengkap yang digunakan oleh guru atau pendidik dalam rangka berkomunikasi dengan siswa atau peserta didik (Arsyad, 2010).

Proses pembelajaran adalah proses komunikasi yang berlangsung dalam suatu sistem, maka dari itu media pembelajaran tersebut menempati posisi yang cukup penting sebagai salah satu komponen sistem pembelajaran. Tanpa adanya media pembelajaran tersebut, komunikasi tidak akan terjadi dan proses belajar mengajar sebagai proses komunikasi juga tidak akan bisa berlangsung secara efektif dan optimal. Jadi, media pembelajaran tersebut bisa dikatakan sebagai komponen integral dari sistem pembelajaran. Penggunaan media pembelajaran bukan hanya dapat menyebabkan proses komunikasi antara guru dan siswa dapat terlaksana dengan baik dan lancar, tetapi dapat merangsang siswa untuk merespon dengan cepat tentang pesan yang disampaikan, sehingga akan berpengaruh pada hasil belajar siswa. Komputer mempunyai potensi untuk menjadi alat pengajaran karena memiliki berbagai kelebihan di antaranya mampu menyajikan objek-objek bergerak dan memadukannya dengan suara, sehingga menjadikan komputer sebagai media yang menarik.

Media pembelajaran berbasis multimedia memegang peranan penting dalam proses pembelajaran. Penggunaan media pembelajaran ini dapat membantu mempermudah pegajar dalam menyampaikan materi pelajaran, dapat menghemat waktu baik persiapan pengajaran maupun dalam proses belajar mengajar dan dapat digunakan berulangulang. Proses pembelajaran yang dilakukan guru dalam memberikan materi pembelajaran, seyogyanya dapat mendemonstrasikan keterampilan yang diajarkan melalui multimedia, guna mendukung penjelasan agar tidak terjadi miskonsepsi. Dalam proses pembelajaran guru memberikan materi didukung dengan perangkat multimedia, maka sangat memungkinkan ingatan siswa akan lebih lama dan memahami materi-materi yang telah diajarkan guru mata diklat. Dewasa ini multimedia dilengkapi dengan alat pengontrol yang disebut dengan multimedia interaktif. Multimedia interaktif dapat dioperasikan oleh 
pengguna, sehingga pengguna dapat memilih apa yang dikehendaki untuk proses selanjutnya. Salah satu tujuan dari pelaksanaan pembelajaran dengan menggunakan multimedia interkatif adalah untuk memberikan perubahan dalam suasana belajar, sehingga dapat menimbulkan motivasi khususnya dalam mengikuti pembelajaran sehingga dapat meningkatkan hasil belajar siswa.

Belajar pada manusia dirumuskan sebagai suatu aktivitas mental / psikis yang berlangsung dalam interaksi aktif dengan lingkungan yang menghasilkan perubahanperubahan dalam pengetahuan, pemahaman, keterampilan dan nilai sikap (Winkel, 1996). Sedangkan menurut Nana Sudjana belajar adalah suatu proses yang ditandai dengan adanya perubahan pada diri seseorang (Sudjana, 2011). Perubahan sebagai hasil proses belajar dapat ditunjukkan dalam berbagai bentuk seperti berubah pengetahuannya, pemahamannya, sikap, dan tingkah lakunya, keterampilannya, kecakapannya dan kemampuannya, daya reaksinya, daya penerimaannya, dan lain-lain. Aspek yang ada pada individu pembelajaran pada dasarnya merupakan proses komunikasi antara guru dan siswa. Sedangkan pembelajaran dalam konsep pembelajaran aktif merupakan suatu proses membimbing siswa dengan mengatur dan mengorganisasi lingkungan sehingga dapat mendorong dan menumbuhkan siswa melakukan kegiatan belajar. Pengajar tersebut berperan sebagai pembimbing, pemimpin, fasilitator dan dinamisator. Sebagai fasilitator guru harus dapat menciptakan kondisi lingkungan menjadi sumber belajar.

Pada jenjang pendidikan SMK, mata diklat banyak berhubungan dengan keterampilan, dengan menekankan pada kegiatan praktikum sesuai bidang keahlian masing-masing. Dalam kegiatan praktik ini semua komponen penilaian mencakup didalamnya, baik ranah kognitif, afektif, maupun psikomotor.
Sesuai dengan tujuan SMK itu sendiri yaitu untuk menghasilkan tenaga kerja menengah yang ahli dibidangnya ditunjang dengan hasil belajar yang baik. Hasil belajar merupakan bukti sejauh mana pemahaman siswa tentang materi pelajaran yang telah diberikan. Ini di perkuat dengan pernyataan Lufri yang mengatakan "setiap proses pembelajaran, keberhasilannya diukur dari seberapa jauh hasil belajar yang dicapai, disamping diukur dari segi prosesnya". Belajar bukan hanya mengingat, akan tetapi lebih luas dari itu, yakni mengalami" (Lufri, 2007). Hasil belajar itu akan timbul jika seseorang memiliki pengetahuan sikap dan keterampilan yang baru setelah melalui proses pembelajaran.

Berdasarkan hasil observasi yang telah dilakukan ditemukan bahwa, hasil belajar siswa SMK N 1 Tanjung Raya pada mata diklat Memperbaiki Motor Listrik masih banyak yang di bawah Kriteria Ketuntasan Minimum (KKM). KKM dari mata diklat Memperbaiki Motor Listrik adalah 72. Adapun hasil belajar siswa dapat dilihat pada Tabel 1.

Tabel 1. Ketuntasan Belajar Siswa Kelas XII TITL Mata Diklat Memperbaiki Motor Listrik.

\begin{tabular}{ccc}
\hline Nilai KKM & $\begin{array}{c}\text { Jumlah } \\
\text { Siswa }\end{array}$ & $\begin{array}{c}\text { Persentase } \\
(\mathbf{\%})\end{array}$ \\
\hline$\geq 72,00$ & 14 & 48,28 \\
\hline$<72,00$ & 15 & 51,72 \\
\hline Total & 29 & 100 \\
\hline
\end{tabular}

Sumber: Guru Mata Diklat Memperbaiki Motor Listrik, data nilai mid semester kelas XII TITL SMK N 1 Tanjung Raya

Berdasarkan Tabel 1 dapat dilihat hasil penilaian siswa pada mata diklat memperbaiki motor listrik, siswa yang lulus pada mata diklat adalah 14 siswa $(48,28 \%)$, sedangkan yang tidak lulus sebanyak 15 siswa $(51,72 \%)$. Persentase siswa yang lulus lebih sedikit dari pada yang tidak lulus. Jadi masih terdapat hasil belajar siswa di bawah KKM. Hasil 
belajar memperbaiki motor listrik masih jauh dari yang diharapkan.

Menurut pengamatan peneliti di sekolah, salah satu penyebabnya adalah dikarenakan guru belum menggunakan media pembelajaran multimedia interaktif dalam mengajar sehingga pemahaman siswa tidak sama ketika memperoleh pelajaran dari guru. Selama ini media yang dibuat guru kurang kreatif sehingga kurangnya daya tarik siswa untuk mengikuti pelajaran dan masih banyak guru yang menggunakan metode ceramah atau konvensional, dimana siswa selalu dituntun untuk mengerjakan sesuatu kegiatan praktik secara rinci, jadi siswa hanya menjalankan perintah-perintah dan petunjuk-petunjuk yang telah diberikan guru, sehingga tidak berkembangnya kreativitas siswa dalam belajar.

Pelajaran memperbaiki motor listrik adalah pelajaran yang membutuhkan daya imajinasi dan logika. Oleh sebab itu perlu diberikan contoh-contoh yang nyata tidak hanya sekedar teori saja. Contoh dalam bentuk nyata akan dapat membantu siswa dalam menumbuhkan imajinasi dan logika yang baik. Pada kenyataannya proses pembelajarannya masih menggunakan pola ceramah atau konvensional. Pola ini pada kenyataannya kurang bisa memvisualisasikan materi terutama materi-materi tentang motor listrik. Selain itu pelajaran motor listrik khususnya untuk materi memperbaiki motor listrik lebih banyak menghabiskan waktu dengan metode ceramah, dan tidak semua siswa bisa memahami materi. Seperti yang kita tahu kebanyakan siswa yang di depan saja yang lebih konsentrasi mendengarkan ceramah dari guru. Proses memperbaiki motor listrik ini sendiri memerlukan suatu media yang didalamnya terdapat unsur-unsur praktis dan siswa dapat memvisualisasikan materi yang disampaikan.

Setelah melakukan observasi ini, perlu diadakan pembaruan untuk media pembelajaran dengan memanfaatkan teknologi komputer khususnya. Salah satu alternatif media pembelajaran yaitu penggunaan multimedia interaktif. Multimedia interaktif ini dirancang khusus dengan menggunakan bermacammacam software yang dipadukan dengan bentuk-bentuk media visual seperti a udio, video, dan persentasi sehingga siswa tidak hanya mendengar, melihat, tapi juga dapat berperan (melakukan sendiri) proses pembelajarannya.

Kelebihan pertama yang menyebutkan bahwa penggunanya bisa berinteraksi dengan komputer adalah bahwa dalam multimedia interaktif terdapat menu-menu khusus yang dapat diklik oleh user untuk memunculkan informasi berupa audio, visual maupun fitur lain yang diinginkan oleh pengguna. Kemudian yang kedua adalah menambah pengetahuan. Pengetahuan disini adalah materi pembelajaran yang dirancang kemudahannya dalam multimedia Interaktif bagi pengguna. Kelebihan ketiga adalah tampilan audio visual yang menarik. Menarik disini tentu saja jika dibandingkan dengan media konvensional seperti buku atau media dua dimensi lainnya. Kemenarikan disini utamanya karena sistem interaksi yang tidak dimiliki oleh media cetak (buku) maupun media elektronik lain (film TV, audio).

Penggunaan multimedia interaktif ini diharapkan dari segi waktu dan kejelasan materi pembelajaran dapat tersampaikan dengan baik. Keindahan suatu media merupakan salah satu sarana agar siswa tidak jenuh dalam mengikuti pelajaran dan efek yang terbesar diharapkan siswa dapat termotivasi untuk mendalami pelajaran tersebut. Penggunaan Multimedia Interaktif ini diharapkan dapat mempermudah siswa dalam menerima materi pelajaran sehingga dapat belajar dengan mudah. Selain itu belajar siswa juga dapat dilakukan di sekolah dan di rumah. Di SMK Negeri 1 Tanjung Raya sudah dilengkapi dengan labor KKPI dan juga LCD proyektor sehingga media pembelajaran multimedia interaktif dapat diterapkan di sekolah ini. Dalam 
pembuatan multimedia interaktif banyak software yang bisa digunakan untuk membuatnya salah satunya adalah Aurora $3 D$ Presentation. Aurora 3D Presentation menawarkan tampilan presentasi tiga dimensi dan memberikan solusi presentasi yang indah dan gaya serta kemudahan dalam menampilkan sebuah file presentasi.

\section{METODE PENELITIAN}

Metode penelitian merupakan suatu cara yang digunakan untuk mengumpulkan, menyusun, menganalisis serta menginterprestasikan data, dan menarik kesimpulan penelitian. Berdasarkan tujuan penelitian yaitu untuk peningkatan hasil belajar pada mata diklat memperbaiki motor listrik melalui media pembelajaran multimedia interaktif. Maka penelitian ini termasuk kedalam penelitian quasi exsperiment (eksperimen semu). Pretest dilakukan sebelum melaksanakan pembelajaran untuk mengetahui pengetahuan awal siswa. Sementara posttest dilaksanakan setelah proses pembelajaran dengan menggunakan multimedia interaktif. Hasil posttest dibandingkan dengan hasil pretest untuk mengetahui peningkatan hasil belajar siswa setelah pembelajaran dengan multimedia interaktif.

Penelitian ini menggunakan desain One Group Pretest-Posttest (Sugiyono, 2014). Sekelompok subjek diberi perlakuan untuk jangka waktu tertentu berupa pembelajaran menggunakan multimedia interaktif. Dalam desain ini, pengukuran dilakukan dua kali. Pengukuran pertama dilakukan sebelum perlakuan. Pengukuran kedua dilakukan setelah perlakuan diberikan.

\section{HASIL}

Multimedia Interaktif ini terdiri dari beberapa menu-menu, mulai dari menu awal (home), materi, latihan, profil, dan lain-lain. Adapun hasil rancangan multimedia interaktif adalah sebagai berikut:

\section{Tampilan Halaman Awal}

Halaman awal ini merupakan pembukaan untuk masuk ke menu utama pada Multimedia Interaktif. Halaman awal pada multimedia interaktif mempunyai satu buah tombol $(G O)$ untuk masuk ke halaman utama. Halaman awal mempunyai animasi masing-masing yang akan terus bergerak hingga multimedia interaktif ditutup. Untuk lebih jelasnya hasil rancangan program dapat dilihat pada gambar 1.

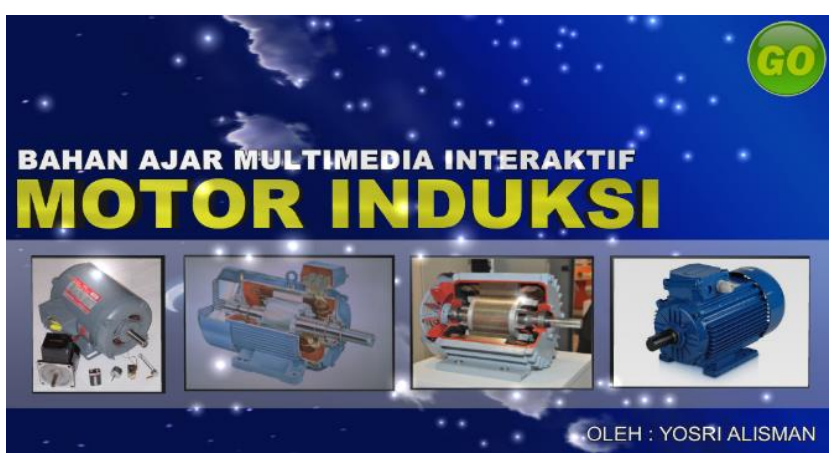

Gambar 1. Tampilan awal multimedia interaktif

\section{Tampilan Menu Utama}

Menu utama dibuat dengan memadukan beberapa komponen yaitu gambar, tombol, teks, suara dan animasi. Pada menu utama terdapat beberapa menu yaitu menu home, materi, latihan, profil dan menu lain-lain. Untuk lebih jelasnya dapat dilihat pada gambar 2 .

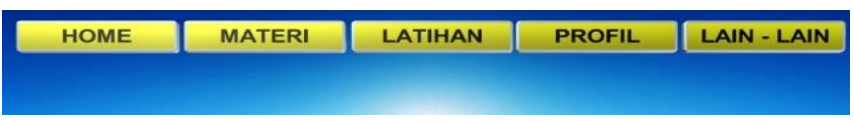

Gambar 2. Tampilan menu utama

\section{Tampilan Menu Materi}

Menu materi di rancang memiliki link ke halaman submateri. Pada halaman submateri ini terdapat beberapa menu yang berisi tentang materi memperbaiki motor listrik yaitu menu motor induksi 1 fasa, motor induksi 3 fasa, menu tentang (gangguan pemeliharaan dan perbaikan) motor induksi, menu cara melilit ulang motor induksi. Halaman submenu materi ini dibangun dengan animasi yang terus 
bergerak dan dilengkapi dengan video. Untuk lebih jelasnya rancangan submenu materi dapat dilihat pada gambar 3.

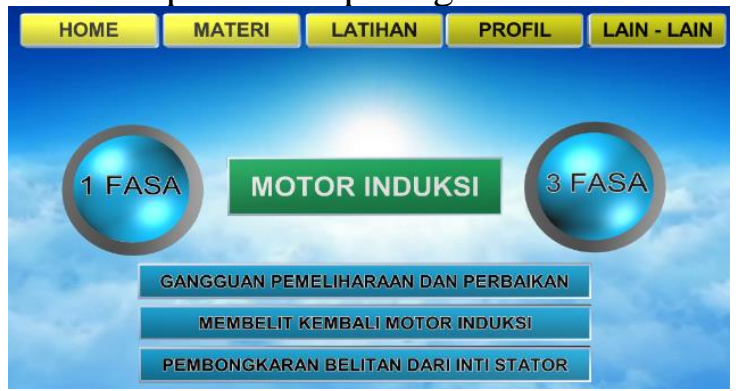

Gambar 3. Tampilan menu materi

\section{Tampilan Menu Latihan}

Menu latihan pada halaman utama mempunyai link ke halaman latihan. Pada halaman latihan siswa diberikan soal-soal tentang materi yang telah diberikan. Menu latihan terdiri dari dua macam latihan yaitu latihan pilihan ganda dan latihan benar atau salah, masing-masing dari latihan terdiri dari 20 soal. Untuk lebih jelasnya dapat dilihat pada gambar 4 .

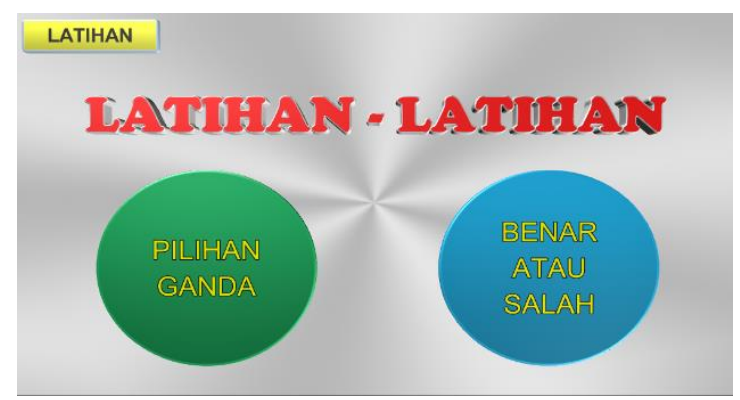

Gambar 4. Tampilan menu latihan

\section{Tampilan Menu Lain-lain}

Menu lain-lain merupakan link ke halaman materi tambahan atau materi pendukung dalam mata diklat memperbaiki motor listrik yang terdiri dari materi tentang hukum biot savart dan video-video cara kerja motor induksi. Untuk lebih jelasnya dapat dilihat pada gambar 6.

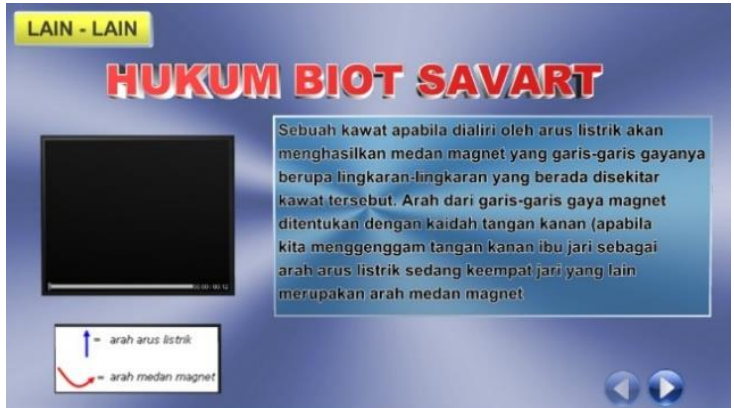

Gambar 6. Tampilan menu lain-lain

Pembuatan multimedia interaktif ini sudah dilakukan validasi isi dengan validatornya guru mata diklat memperbaiki motor listrik. Setelah dilakukan validasi isi disimpulkan bahwa multimedia interaktif ini sudah sesuai dengan silabus, RPP, dan bahan ajar mata diklat memperbaiki motor listrik yang ada di SMK Negeri 1 Tanjung Raya.

\section{Analisis Data \\ Uji normalitas}

Untuk melihat apakah data dari kelas subyek penelitian terdistribusi normal, maka dilakukan uji normalitas pada pretest dan posttest, uji normalitas menggunakan metode chi-kuadrat dengan perhitungan manual seperti terlihat pada Tabel 2.

Pengujian diperoleh dari perbandingan harga $X^{2}$ hitung $<X^{2}$ Tabel pada subyek penelitian pada taraf signifikansi $\alpha=0,05$ pada derajat kebebasan $(\mathrm{dk})=\mathrm{k}-1=5$. Perhitungan lebih lengkap uji normalitas diperoleh dari Tabel 2.

Tabel 2. Rangkuman Uji Normalitas Pretest dan Postest

\begin{tabular}{ccccc}
\hline $\begin{array}{c}\text { Kelas } \\
\text { Eksperimen }\end{array}$ & $\mathrm{N}$ & $\begin{array}{c}\mathrm{X}^{2} \\
\text { hitung }\end{array}$ & $\mathrm{X}^{2}$ Tabel & Distribusi \\
\hline Pretest & 29 & 5,1281 & 11,070 & Normal \\
\hline Posttest & 29 & 1,384 & 11,070 & Normal \\
\hline
\end{tabular}

Tabel 2 merupakan hasil perhitungan manual dilihat bahwa $\mathrm{X}^{2}$ hitung $<\mathrm{X}^{2}$ Tabel ini berarti bahwa data yang didapatkan dari kelas subyek penelitian ini terdistribusi normal. 


\section{Peningkatan Hasil Belajar}

Tabel 3. Peningkatan Hasil Belajar

\begin{tabular}{|c|c|c|c|c|}
\hline Responden & $\begin{array}{c}\text { Nilai } \\
\text { Pretest }\end{array}$ & $\begin{array}{c}\text { Nilai } \\
\text { Posttest }\end{array}$ & NG & Kategori \\
\hline 1 & 50 & 70 & 0,4 & Sedang \\
\hline 2 & 70 & 85 & 0,5 & Sedang \\
\hline 3 & 70 & 80 & 0,33 & Sedang \\
\hline 4 & 65 & 70 & 0,14 & Rendah \\
\hline 5 & 70 & 80 & 0,33 & Sedang \\
\hline 6 & 55 & 70 & 0,33 & Sedang \\
\hline 7 & 45 & 65 & 0,36 & Sedang \\
\hline 8 & 40 & 45 & 0,08 & Rendah \\
\hline 9 & 70 & 80 & 0,33 & Sedang \\
\hline 10 & 65 & 75 & 0,29 & Rendah \\
\hline 11 & 70 & 80 & 0,33 & Sedang \\
\hline 12 & 60 & 75 & 0,38 & Sedang \\
\hline 13 & 65 & 80 & 0,43 & Sedang \\
\hline 14 & 75 & 95 & 0,8 & Tinggi \\
\hline 15 & 70 & 85 & 0,5 & Sedang \\
\hline 16 & 60 & 70 & 0,25 & Rendah \\
\hline 17 & 70 & 85 & 0,5 & Sedang \\
\hline 18 & 65 & 80 & 0,43 & Sedang \\
\hline 19 & 70 & 90 & 0,67 & Sedang \\
\hline 20 & 60 & 70 & 0,25 & Rendah \\
\hline 21 & 80 & 95 & 0,75 & Tinggi \\
\hline 22 & 75 & 85 & 0,4 & Sedang \\
\hline 23 & 55 & 55 & - & Tetap \\
\hline 24 & 65 & 80 & 0,43 & Sedang \\
\hline 25 & 60 & 70 & 0,25 & Rendah \\
\hline 26 & 65 & 80 & 0,43 & Sedang \\
\hline 27 & 75 & 85 & 0,4 & Sedang \\
\hline 28 & 55 & 60 & 0,11 & Rendah \\
\hline 29 & 70 & 80 & 0,33 & Sedang \\
\hline Rata-rata & 64,48 & 75,07 & 0,38 & Sedang \\
\hline
\end{tabular}

Data peningkatan hasil belajar siswa kelas eksperimen diperoleh dengan membandingkan tes awal (pretest) dan tes akhir (posttest), yang diikuti 29 orang siswa seperti Tabel 3. Berdasarkan hasil analisis pada Tabel 3 dapat dilihat bahwa rata-rata peningkatan hasil belajar siswa termasuk dalam kategori sedang. Dengan demikian dapat dijelaskan bahwa hasil belajar siswa setelah pembelajaran dengan menggunakan media pembelajaran multimedia interaktif mengalami peningkatan.

\section{PEMBAHASAN}

Pada penelitian eksperimen ini menggunakan uji Gain Score (NG). Yang pertama dilakukan pretest untuk melihat kemampuan awal siswa sebelum diberi perlakuan. Dari hasil pretest diperoleh hasil belajar rata-rata sebesar $=64,48$. Kemudian dilakukan uji normalitas dan didapat bahwa data terdistribusi normal. Setelah melihat kemampuan awal maka diberi perlakuan menggunakan media pembelajaran multimedia interaktif $3 \mathrm{kali}$ pertemuan selama 3 minggu kemudian diberi posttest. Dari hasil perhitungan data setelah perlakuan didapatkan mean = 75,07 , simpangan baku $=10,85$, skor tertinggi $=95$, skor terendah $=45$, banyak kelas interval $=6$, dan panjang kelas interval $=9$ dan diperoleh $\mathrm{X}^{2}$ hitung $=1,384$. Dengan banyaknya data $29 \mathrm{dan} \mathrm{dk}=5$ maka diperoleh $\mathrm{X}^{2}$ Tabel $=11,07$ dengan demikian $\mathrm{X}^{2}$ hitung $<\mathrm{X}^{2}$ Tabel, ini berarti nilai hasil belajar Memperbaiki Motor Listrik terdistribusi normal.

Langkah berikutnya adalah melihat peningkatan hasil belajar siswa dengan menggunakan gain score, didapat 2 orang siswa mengalami peningkatan kategori tinggi, 19 orang siswa mengalami peningkatan kategori sedang, 7 orang 
siswa mengalami peningkatan kategori rendah, dan hanya satu orang siswa yang tidak mengalami peningkatan. Sedangkan secara keseluruhan rata-rata hasil belajar siswa mengalami peningkatan dengan kategori sedang.

Dari penjelasan di atas, pembelajaran dengan menggunakan multimedia interaktif dapat meningkatkan hasil belajar siswa, karena adanya peninggkatan hasil belajar yang signifikan antara pretest dan posttest.

Berdasarkan urian diatas kegiatan pembelajaran menggunakan multimedia interaktif dapat meningkatkan hasil belajar siswa. Dengan menggunakan multimedia interaktif proses pembelajaran jadi menyenangkan dan mudah dipahami, sehingga memperoleh hasil belajar yang lebih baik pada kompetensi dasar pemeliharaan, perbaikan dan melilit ulang kumparan motor induksi di bandingkan dengan pembelajaran tanpa menggunakan multimedia interaktif.

Hasil penelitian ini diperkuat oleh penelitian Irwanto Zarma Putra menunjukan bahwa terdapat peningkatan hasil belajar siswa melalui penerapan Multimedia di kelas X TITL B SMK Negeri 2 Sawahlunto, setelah mengikuti pembelajaran Menganalisis Rangkaian Listrik dengan penggunaan Multimedia, persentase ketuntasan hasil belajar siswa pada siklus pertama mencapai $68.42 \%$, meningkat menjadi $84.21 \%$ pada siklus kedua dan meningkat menjadi $89.47 \%$ pada siklus ketiga. Hal ini berarti bahwa hasil belajar siswa pada mata pelajaran Menganalisis Rangkaian Listrik di kelas X TITIL B SMK Negeri 2 Sawahlunto telah mencapai ketuntasan klasikal (Putra, 2012).

\section{KESIMPULAN}

Berdasarkan analisis data penelitian yang telah dilakukan, maka dapat disimpulkan bahwa terdapat peningkatan hasil belajar siswa dengan pembelajaran menggunakan media pembelajaran multimedia interaktif pada mata diklat
Memperbaiki Motor Listrik di SMK Negeri 1 Tanjung Raya. Hal ini berdasarkan hasil belajar siswa dengan menggunakan media pembelajaran multimedia interaktif memiliki rata-rata pretest 64,48 dan rata-rata posttest 75,07 dan uji gain score didapat 2 orang siswa mengalami peningkatan kategori tinggi, 19 orang siswa mengalami peningkatan kategori sedang, 7 orang siswa mengalami peningkatan kategori rendah, dan hanya satu orang siswa yang tidak mengalami peningkatan. Sedangkan secara keseluruhan rata-rata hasil belajar siswa mengalami peningkatan dengan kategori sedang.

\section{REFERENSI}

Arsyad, A. (2010). Media Pembelajaran. Jakarta: Raja Grafindo Persada.

Candra, O., Pulungan, A. B., Eliza, F., Elfizon, \& Syamsuarnis. (2019). Development of Miniature Secondary Network of Electric Power Distribution System as a Learning Media for Electrical Engineering Students. In The 1st International Conference on Vocational Education and Technology. https://doi.org/10.1088/17426596/1165/1/012015

Elfizon, Syamsuarnis, \& Candra, O. (2017). The Effect of Strategy of Training Models in Learning Electrical Installation. In 4th International Conference on Technical and Vocation Education and Training (pp. 138-141). Padang: UNP Press.

Lufri. (2007). Strategi Pembelajaran Biologi Teori, Praktek dan Penelitian. Padang: UNP Press.

Putra, I. Z. (2012). Peningkatan Hasil Belajar Menganalisis Rangkaian Listrik Di SMK Negeri 2 Sawahlunto Melalui Penggunaan Multimedia. Universitas Negeri Padang.

Sudjana, N. (2011). Penilaian Hasil 
Proses Belajar Mengajar. Bandung: PT. Remaja Rosdakarya.

Sugiyono. (2014). Statistika untuk Penelitian. Bandung: CV. Alfabeta.

Winkel, W. S. (1996). Psikologi Pengajaran. Jakarta: Grasindo.

Zaus, M. A., Wulansari, R. E., Islami, S.,
\& Pernanda, D. (2018). Perancangan Media Pembelajaran Listrik Statis dan Dinamis Berbasis Android. INTECOMS: Journal of Information Technology and Computer Science, $1(1), 1-7$. 